\title{
Specific Conductance
}

Chapter 6.3 of

Section A, National Field Manual for the Collection of Water-Quality Data Book 9, Handbooks for Water-Resources Investigations
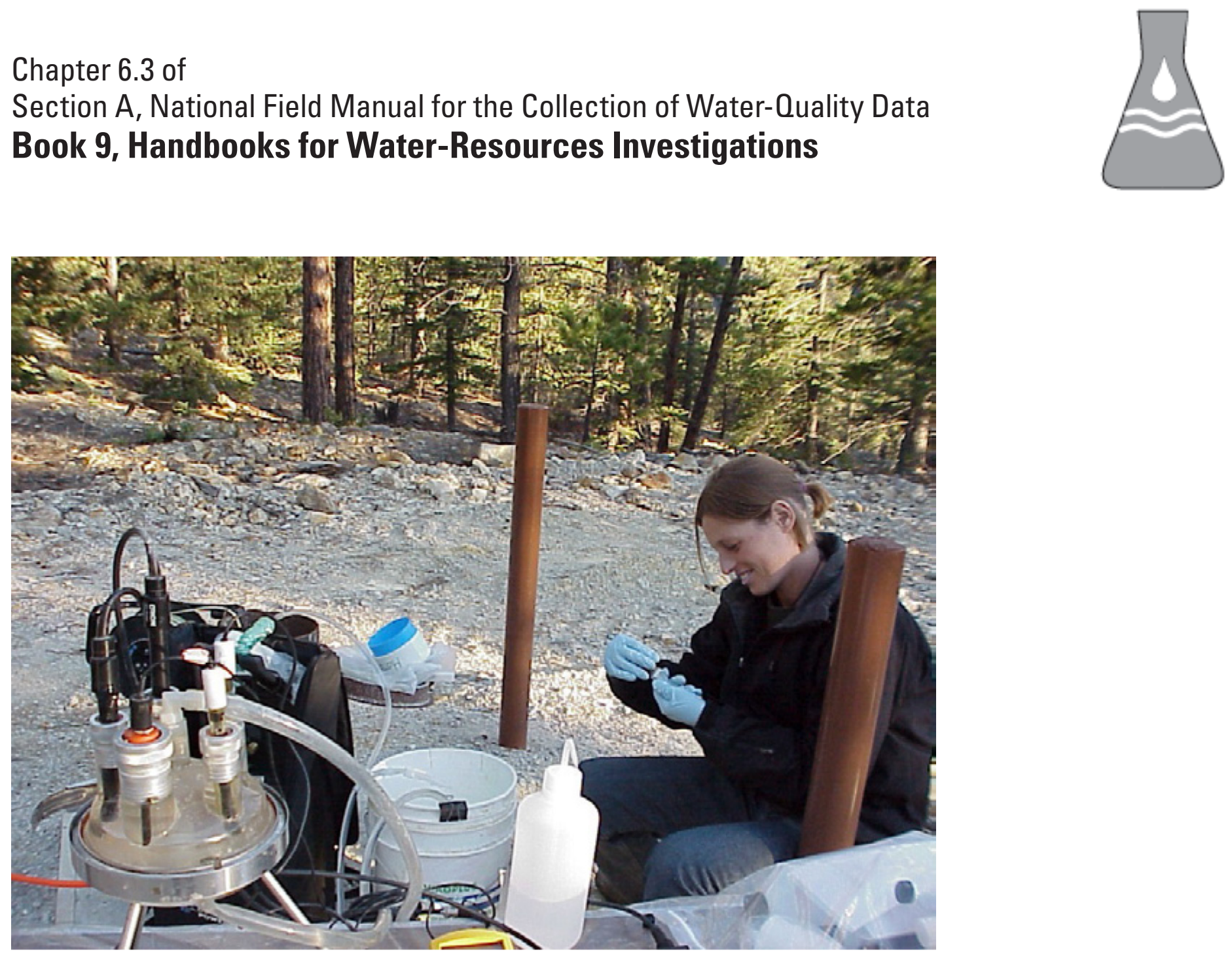

Techniques and Methods 9-A6.3

Supersedes USGS Techniques of Water-Resources Investigations, Book 9, Chapter A6.3, Version 1.2 
Cover: Photograph of researcher measuring specific conductance, $\mathrm{pH}$, and temperature by using a flow-through cell to isolate the water from the atmosphere and preserve measurement integrity, Red River Basin, New Mexico. Photograph by James Ball, U.S. Geological Survey. 


\section{Specific Conductance}

By U.S. Geological Survey

Chapter 6.3 of

Section A, National Field Manual for the Collection of Water-Quality Data

Book 9, Handbooks for Water-Resources Investigations

Techniques and Methods 9-A6.3

Supersedes USGS Techniques of Water-Resources Investigations,

Book 9, Chapter A6.3, Version 1.2

\section{U.S. Department of the Interior}

U.S. Geological Survey 


\title{
U.S. Department of the Interior DAVID BERNHARDT, Acting Secretary
}

\author{
U.S. Geological Survey \\ James F. Reilly II, Director
}

U.S. Geological Survey, Reston, Virginia

First release: April 1998, online as Techniques of Water-Resources Investigations (TWRI), book 9, chapter A6.3, version 1.0

Revised: August 2005, online as TWRI, book 9, chapter A6.3, version 1.2

Revised: February 2019, online as Techniques and Methods, book 9 , chapter A6.3

For more information on the USGS - the Federal source for science about the Earth, its natural and living resources, natural hazards, and the environment-visit https://www.usgs.gov or call 1-888-ASK-USGS.

For an overview of USGS information products, including maps, imagery, and publications,

visit https://store.usgs.gov.

Any use of trade, firm, or product names is for descriptive purposes only and does not imply endorsement by the U.S. Government.

Although this information product, for the most part, is in the public domain, it also may contain copyrighted materials as noted in the text. Permission to reproduce copyrighted items must be secured from the copyright owner.

Suggested citation:

U.S. Geological Survey, 2019, Specific conductance: U.S. Geological Survey Techniques and Methods, book 9, chap. A6.3, 15 p., https://doi.org/10.3133/tm9A6.3. [Supersedes USGS Techniques of Water-Resources Investigations, book 9, chap. A6.3, version 1.2.]

ISSN 2328-7055 (online) 


\section{Contents}

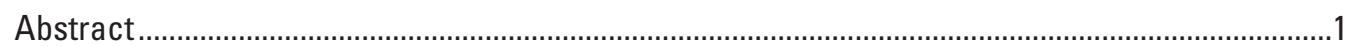

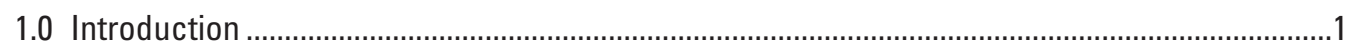

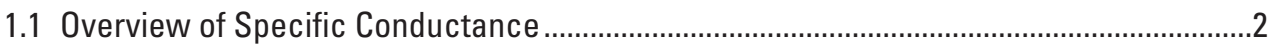

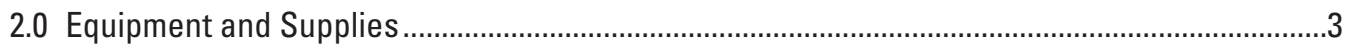

2.1 Electrical Conductivity Cells and Specific Conductance Meters.........................................

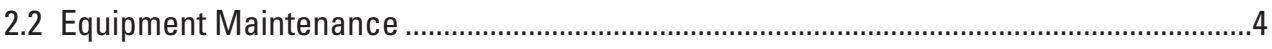

2.2.1 Conductivity Probe Cleaning, Storage, and Maintenance ....................................

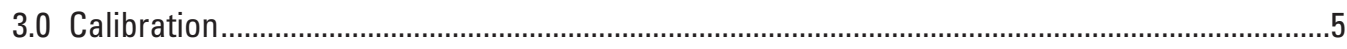

3.1 One-Point Calibration—Determination of the Cell Constant.............................................

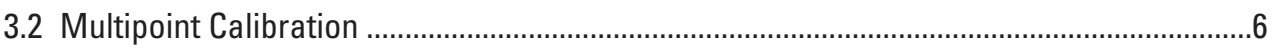

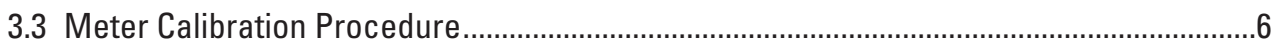

4.0 Measurement of Specific Conductance..............................................................................

4.1 Measurement of Specific Conductance in Surface Water ................................................

4.1.1 In Situ Measurement of Specific Conductance in Surface Water...........................8

4.1.2 Measurement of Specific Conductance on a Subsample from Surface

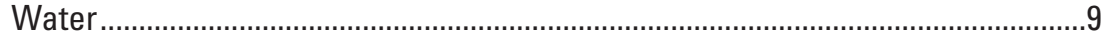

4.2 Measurement of Specific Conductance in Groundwater..............................................10

4.2.1 Measurement of Specific Conductance in a Well ..............................................10

4.2.2 Measurement of Specific Conductance on a Subsample from a Well ..................11

4.3 Measurement of Specific Conductance of a Water Sample with Low or High pH .........12

4.3.1 Measurement of Specific Conductance of a Water Sample with Low pH $(<4)$..............................................................................................12

4.3.2 Measurement of Specific Conductance of a Water Sample

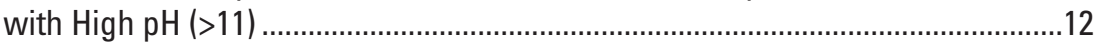

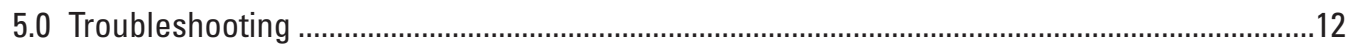

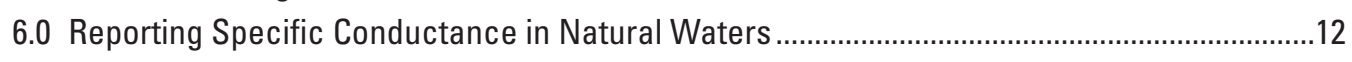

6.1 Uncertainty in Measurements of Specific Conductance ...............................................12

7.0 Applications of Specific Conductance in Surface Water and Groundwater ............................13

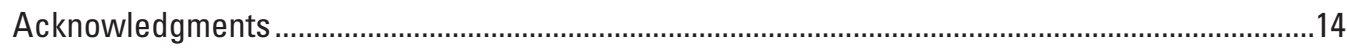

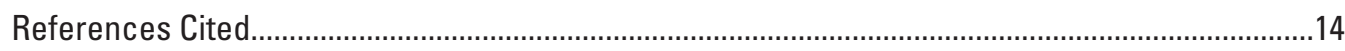

\section{Figure}

6.3-1. Diagram showing general guidelines for selecting an electrical conductivity probe with the optimum cell constant

\section{Tables}

6.3-1. Equipment and supplies used to measure specific conductance in the field ............3

6.3-2. Electrical conductivity of molality-based primary $\mathrm{KCl}$ standards ..............................

6.3-3. Troubleshooting guide for measurements of specific conductance ........................13 


\section{Conversion Factors}

International System of Units to U.S. customary units

\begin{tabular}{lcl}
\hline \multicolumn{1}{c}{ Multiply } & By & To obtain \\
\hline & Length & \\
\hline centimeter $(\mathrm{cm})$ & 0.3937 & inch (in.) \\
\hline \multicolumn{3}{c}{ Volume } \\
\hline cubic centimeter $\left(\mathrm{cm}^{3}\right)$ & 0.06102 & cubic inch $\left(\right.$ in $\left.^{3}\right)$ \\
\hline gram $(\mathrm{g})$ & 0.03527 & ounce, avoirdupois $(\mathrm{oz})$ \\
kilogram $(\mathrm{kg})$ & 2.205 & pound, avoirdupois $(\mathrm{lb})$ \\
\hline
\end{tabular}

Temperature in degrees Celsius $\left({ }^{\circ} \mathrm{C}\right)$ may be converted to degrees Fahrenheit ( $\left.{ }^{\circ} \mathrm{F}\right)$ as follows:

$$
{ }^{\circ} \mathrm{F}=\left(1.8 \mathrm{x}^{\circ} \mathrm{C}\right)+32
$$

Specific conductance is reported in microsiemens per centimeter at 25 degrees Celsius $(\mu \mathrm{S} / \mathrm{cm}$ at $25^{\circ} \mathrm{C}$ ). Siemens per centimeter are the equivalent of mhos per centimeter.

Molality of a solution is the number of moles $(\mathrm{mol})$ of a constituent per kilogram $(\mathrm{kg})$ of solution. Units of molality are reported in $\mathrm{mol} / \mathrm{kg}$.

\section{Abbreviations and Symbols}

$\begin{array}{ll}\text { ABS } & \text { acrylonitrile butadiene styrene } \\ \text { ASR } & \text { Analytical Services Request } \\ \text { cm } & \text { centimeter } \\ \text { DIW } & \begin{array}{l}\text { quality-assured deionized water with resistance greater than or equal to } 18 \\ \text { megaohms (M } 2 \text { ) }\end{array} \\ \text { EDI } & \text { equal-discharge increment, isokinetic sampling method } \\ \text { EWI } & \text { equal-width increment, isokinetic sampling method } \\ \text { G } & \text { electrical conductance } \\ \text { HIF } & \text { Hydrologic Instrumentation Facility at Stennis Space Center, Mississippi (USGS) } \\ \text { L } & \text { liter } \\ \text { m } & \text { molality } \\ \text { HS/cm } & \text { microsiemen per centimeter } \\ \text { mol/kg } & \text { mole per kilogram } \\ \text { NFM } & \text { National Field Manual for the Collection of Water-Quality Data (USGS) } \\ \text { NFSS } & \text { National Field Supply Service, also referred to as “One Stop" (USGS) } \\ \text { NIST } & \text { National Institute of Standards and Technology } \\ \text { NWIS } & \text { National Water Information System (USGS) } \\ \text { NWOL } & \text { National Water Quality Laboratory (USGS) }\end{array}$




$\begin{array}{ll}\text { PCFF } & \text { personal computing field form } \\ \text { PVDF } & \text { polyvinylidene fluoride } \\ \text { OSB } & \text { Quality Systems Branch (USGS) } \\ R & \text { electrical resistance } \\ \text { SOP } & \text { standard operating procedure } \\ \text { SRS } & \text { standard reference sample } \\ \text { TDS } & \text { total dissolved solids } \\ \text { USGS } & \text { U.S. Geological Survey } \\ \text { WMA } & \text { Water Mission Area (USGS) } \\ \kappa & \text { electrical conductivity } \\ > & \text { greater than } \\ < & \text { less than } \\ \leq & \text { less than or equal to } \\ \text { M } \Omega & \text { megaohm } \\ \Omega & \text { ohm } \\ \alpha & \text { temperature-compensation factor }\end{array}$

\section{Chemical Formulas}

$\mathrm{CO}_{2}$ carbon dioxide

$\mathrm{H}_{2} \mathrm{O}$ water

$\mathrm{HCl}$ hydrochloric acid

$\mathrm{HNO}_{3}$ nitric acid

$\mathrm{KCl}$ potassium chloride

$\mathrm{NaCl}$ sodium chloride 


\section{Requirements and Recommendations}

As used in the U.S. Geological Survey (USGS) "National Field Manual for the Collection of Water-Quality Data" (NFM), the terms "required" and "recommended" have the USGSspecific meanings described below:

- The terms "require," "required," and "requirements" in reference to USGS protocols indicate that USGS Water Mission Area (WMA) policy has been established on the basis of research or consensus of the technical staff, and has been reviewed by waterquality specialists and other professionals having the appropriate expertise. Technical memorandums and other documents that define USGS WMA policy are cited in the NFM. USGS field personnel are instructed to use required equipment and procedures as described in the NFM. Departure from or modifications to stipulated requirements, if necessary for accomplishing specific data-quality requirements or study objectives, must be independently quality assured and documented (Office of Water Quality Technical Memorandum 2002.13-U.S. Geological Survey, 2002).

- The terms "recommend," "recommended," and "recommendation" indicate that, on the basis of research or consensus, there are several acceptable alternatives to a given procedure or equipment selection in the NFM. Relevant technical memorandums and publications pertinent to such recommendations are cited in the NFM to the extent that such documents are available. Specific requirements, data-quality objectives, or other constraints of a project may affect the choice of recommended equipment or procedures. Selection from among the recommended alternatives should be based on referenced research and sound field judgment, and reasons for the selection must be documented. Departures from or modifications to the recommended procedures must be independently quality assured and documented (Office of Water Quality Technical Memorandum 2002.13-U.S. Geological Survey, 2002). 


\title{
Chapter 6.3. Specific Conductance
}

\author{
By U.S. Geological Survey
}

\section{Abstract}

The "National Field Manual for the Collection of WaterQuality Data" (NFM) provides guidelines and procedures for U.S. Geological Survey (USGS) personnel who collect data used to assess the quality of the Nation's surface-water and groundwater resources. This chapter, NFM A6.3, provides guidance and protocols for the measurement of specific conductance of a water sample, which include the scientific basis of the measurement, selection and maintenance of equipment, calibration, troubleshooting, and procedures for measurement and reporting. It updates and supersedes USGS Techniques of Water-Resources Investigations, book 9, chapter A6.3, version 1.2, by D.B. Radtke, J.V. Davis, and F.D. Wilde.

Specific conductance is routinely measured when water samples are collected, is often measured continually at USGS streamgages, and is a parameter regularly measured during laboratory and field experiments. The field method for measuring specific conductance described in this chapter is applicable to most natural waters.

Before 2017, the NFM chapters were released in the USGS Techniques of Water-Resources Investigations series. Effective in 2018, new and revised NFM chapters are being released in the USGS Techniques and Methods series; this series change does not affect the content and format of the NFM. More information is in the general introduction to the NFM (USGS Techniques and Methods, book 9, chapter A0) at https://doi.org/10.3133/tm9A0. The authoritative current versions of NFM chapters are available in the USGS Publications Warehouse at https://pubs.er.usgs.gov. Comments, questions, and suggestions related to the NFM can be addressed to nfm@usgs.gov.

\subsection{Introduction}

The "National Field Manual for the Collection of WaterQuality Data" (NFM) is the official and citable protocol for the collection of water-quality data by the Water Mission Area (WMA) of the U.S. Geological Survey (USGS). The NFM provides guidelines and procedures for USGS personnel who collect data for water quality in surface water and groundwater, with detailed, comprehensive, and citable procedures.

National USGS program and project personnel who collect water-quality data, as well as those in USGS Water Science Centers and including those conducting projects supported by the USGS Cooperative program, are mandated to use protocols provided in the NFM (USGS Office of WaterQuality Technical Memorandum 2002.13-U.S. Geological Survey, 2002). Formal training, as provided in the USGS class "Field Water-Quality Methods for Groundwater and Surface Water," and field apprenticeships supplement the information provided in the NFM and are needed to collect unbiased, highquality data.

The USGS National Field Manual provides detailed, comprehensive, and citable procedures for monitoring the quality of surface water and groundwater. Formal training and field apprenticeships supplement the information provided in the NFM.

Chapter A6.3 of the NFM provides guidance and protocols for the measurement of specific conductance of a water sample, which may be applied in both laboratory and field settings. Specific conductance, also called electrical conductivity, is a water-quality property whose value is proportional to the collective concentration of ions in solution. The specific conductance measurement depends on the concentration of ions and the temperature of the solution. The measurement is straightforward and precise with many environmental applications. Specific conductance is routinely measured when water samples are collected, is often measured continually at USGS streamgages, and is regularly measured during laboratory and field experiments.

This chapter updates and supersedes USGS Techniques of Water-Resources Investigations, book 9, chapter A6.3, version 1.2 (Radtke and others, 2005). It covers the physical basis for measurement of specific conductance in aqueous solutions, as well as factors that affect the measurement, terminology, method protocols, and applications. The field method described in this chapter is applicable to most natural waters. 
Before 2017, the USGS NFM chapters were released in the USGS Techniques of Water-Resources Investigations series. Effective in 2018, new and revised NFM chapters are being released in the USGS Techniques and Methods series; this series change does not affect the content and format of the NFM. More information is in the general introduction to the NFM (USGS Techniques and Methods, book 9, chapter A0-U.S. Geological Survey, 2018) at https://doi.org/10.3133/tm9A0. The authoritative current versions of NFM chapters are available in the USGS Publications Warehouse at https://pubs.er.usgs.gov. Comments, questions, and suggestions related to the NFM can be addressed tonfm@usgs.gov.

\subsection{Overview of Specific Conductance}

Specific conductance is an indirect measure of the collective concentration of dissolved ions in solution, and is defined as the electrical conductance of 1 cubic centimeter $\left(\mathrm{cm}^{3}\right)$ of a solution at 25 degrees Celsius $\left({ }^{\circ} \mathrm{C}\right)(\mathrm{Hem}, 1982)$. The terms "specific conductance," "specific electrical conductance," and "electrical conductivity" have been used interchangeably in the literature to report the same measurement. Because the term "electrical conductivity" is not always referenced to a standard temperature, the measurement or reference temperature must be reported with this parameter. The USGS National Water Information System (NWIS) reports the measurement of electrical conductance as specific conductance at $25^{\circ} \mathrm{C}$, meaning that at any temperature for which the measurement is made, the value is corrected to what it would be at $25^{\circ} \mathrm{C}$. The term "specific conductance" is correctly defined as the electrical conductance of $1 \mathrm{~cm}^{3}$ of a solution at $25^{\circ} \mathrm{C}$. If the electrical conductance is measured at another temperature, the value is corrected to what it would be at $25^{\circ} \mathrm{C}$ and reported as specific conductance at $25^{\circ} \mathrm{C}$. Most modern specific conductance meters are temperature compensated and report the corrected value automatically.

The term "specific conductance" is correctly defined as the electrical conductance of 1 cubic centimeter of a solution at $25^{\circ} \mathrm{C}$. If the electrical conductance is measured at another temperature, the value is corrected to what it would be at $25^{\circ} \mathrm{C}$ and reported as specific conductance at $25^{\circ} \mathrm{C}$.

In aqueous solutions, electrical conductance ( $G$, measured in siemens [S]) is the inverse of electrical resistance $(R$, measured in ohms $[\Omega]$ ), and is the capacity of water to conduct an electric current as a result of the movement of ions through the solution. Electrical conductivity $(\kappa)$ is a measure of the electrical conductance $(G)$ of a substance normalized to a unit length and cross-sectional area.
The electrical conductivity of a solution can be determined by using the following equation:

$$
\kappa=K_{\text {cell }} G
$$

where $K_{\text {cell }}$ is the cell constant (in units of $\mathrm{cm}^{-1}$ ). The cell constant is the ratio of the distance between two electrode plates $(d)$ and their area $(A)$. The units of electrical conductivity are siemens per centimeter $(\mathrm{S} / \mathrm{cm})$, which is the equivalent of mhos per centimeter $(\mathrm{mhos} / \mathrm{cm})$. Most values reported prior to 1971 were in units of mhos per centimeter.

Electrical conductivity increases by 0.5 to 3 percent per degree Celsius and varies depending on the ionic species present (Robinson and Stokes, 1970; McCleskey, 2013). For natural waters, conductometric measurements are typically used to estimate the concentrations of total dissolved solids (TDS); therefore, the electrical conductivity is reported at $25^{\circ} \mathrm{C}\left(\kappa_{25^{\circ} \mathrm{C}}\right.$, which is equivalent to specific conductance), to facilitate this estimation of TDS by removing the effects of temperature. The value of $\kappa_{25}{ }^{\circ} \mathrm{C}$ is typically calculated by using the following equation:

$$
\kappa_{25^{\circ} \mathrm{C}}=\frac{\kappa}{1+\alpha\left(t-25^{\circ} \mathrm{C}\right)}
$$

where $\alpha$ is the temperature-compensation factor and $t$ is the measured temperature in degrees Celsius. Modern specific conductance field meters typically have preprogrammed temperature-compensation factors $(\alpha)$ and report specific conductance (or electrical conductivity) at $25^{\circ} \mathrm{C}\left(\kappa_{25}{ }^{\circ} \mathrm{C}\right)$. Most specific conductance meters utilize either linear (0.019-0.020 per $^{\circ} \mathrm{C}$ ) or nonlinear (International Organization for Standardization, 1985) temperature-compensation algorithms that are applicable for most natural waters. The temperature compensation used is likely described in the meter's manual or can be determined by using standard solutions and the method described by McCleskey (2013). Conductance and temperature can be measured accurately with modern instrumentation, and temperature compensation is typically accurate to \pm 5 percent for water in the range from 5 to $35^{\circ} \mathrm{C}$ and whose $\mathrm{pH}$ is between 4 and 11 . For low-pH $(\mathrm{pH}<4)$ waters, using the standard temperature-compensation factors can result in $\kappa_{25}{ }^{\circ} \mathrm{C}$ errors as large as 50 percent, because the transport properties of the hydrogen ion are different from those of most other ions, and the hydrogen ion contributes substantially to the electrical conductance at low $\mathrm{pH}$ (McCleskey, 2013). For low-pH waters, temperature corrections may represent the largest source of error. A temperature-compensation method applicable to low-pH waters is described in section 4.3 below and by McCleskey (2013). No temperaturecompensation method is available for waters with $\mathrm{pH}$ greater than 11; therefore, the specific conductance in high-pH waters should be checked by measuring at ambient temperature and 
then again at $25{ }^{\circ} \mathrm{C}$. Additional sources of uncertainty when measuring specific conductance include calibration, preparation of standard solutions, fouling or contamination of the conductivity cell, and improper maintenance of the specific conductance meter and probe. The method described here is intended to produce accurate and precise specific conductance measurements over a wide range of solution composition, $\mathrm{pH}$, and temperature. The USGS typically reports the electrical conductivity of water as specific conductance in units of microsiemens per centimeter $(\mu \mathrm{S} / \mathrm{cm})$ at $25^{\circ} \mathrm{C}$.

The USGS typically reports the electrical conductivity of water as specific conductance in units of microsiemens per centimeter $(\mu \mathrm{S} / \mathrm{cm})$ at $25^{\circ} \mathrm{C}$.

\subsection{Equipment and Supplies}

High-quality specific conductance meters, including multiparameter sondes, are available commercially. Most modern specific conductance meters have built-in temperature compensation and are accurate (typically within \pm 5 percent) for waters with a $\mathrm{pH}$ between 4 and 11 and in the temperature range from 5 to $35^{\circ} \mathrm{C}$.

This section provides detailed information on the measurement of specific conductance that is applicable to most meters. Users must be familiar with the instructions provided by the manufacturer to develop a standard operating procedure (SOP) for calibration and measurement for each meter. The SOP should combine the requirements of this chapter of the NFM with the recommendations of the manufacturer to standardize instrument operations for users. Every specific conductance meter should be accompanied by a log for recording calibrations, cell constants, and repairs. Typical supplies used for field measurement of specific conductance are listed in table 6.3-1.

Most modern specific conductance meters have built-in temperature compensation and are accurate (typically within \pm 5 percent) for waters with a $\mathrm{pH}$ between 4 and 11 and in the temperature range from 5 to $35^{\circ} \mathrm{C}$.

\subsection{Electrical Conductivity Cells and Specific Conductance Meters}

There are several types of conductivity cells. A dipstyle conductivity cell is integrated into a probe, is adaptable to many measurement situations, and is commonly used in modern field specific conductance meters and multiparameter
Table 6.3-1. Equipment and supplies used to measure specific conductance in the field.

[Modify this list to meet the specific needs of the field effort]

\section{Equipment and supplies}

- Specific conductance meter with probe, thermistor, and builtin temperature compensation

- Instruction manual

- Log book (physical or electronic) for recording cell constant, calibrations, maintenance, and repairs

- Specific conductance standards

- Deionized water for rinsing

- Flow-through cell

- Paper tissue for cleaning and drying

- Disposable laboratory gloves and glasses

- Flasks or beakers

- Waste-disposal container

- Multiparameter sonde sensor guard and calibration cup

- Spare electrical conductivity probe

- Spare batteries

sondes. Probes containing dip conductivity cells are straightforward to use as they are immersed in the water during measurement, can be used in flowing or static waters, and are relatively easy to clean and maintain. Other less commonly used conductivity cells include a cup with built-in electrodes that hold the sample during measurement and a flow-through conductivity cell that is connected to a fluid line that maintains a closed system during measurement. In addition to the cell type, the material used in the cell body (epoxy or plastic - for example, acrylonitrile butadiene styrene (ABS) or polyvinylidene fluoride [PVDF]), stainless steel, or Pyrex glass) and electrodes (graphite, platinum, or platinum-iridium) should be considered when selecting equipment. Probes constructed of epoxy, plastic, or stainless steel with graphite electrodes are well suited for field use, whereas Pyrex glass probes with platinum-iridium electrodes are more fragile and better suited for laboratory use. Modern conductivity cells generally contain thermistors used for automatic temperature compensation. Thermistors should be checked on a regular basis to assure optimum performance; malfunctioning thermistors will produce erroneous specific conductance values. Because probes are used more commonly for field measurements, this chapter focuses on their use; however, similar procedures and criteria should be used when using conductivity cups or flow-through conductivity cells.

Specific conductance meters have an optimal range for measurement of conductance; for modern meters, this range can be large because of built-in auto-ranging capabilities. Manufacturer's recommendations for the appropriate range 
of each meter should be followed, although most field meters in use today have auto-ranging capability. Also, a conductivity probe with a suitable cell constant for the types of waters being measured should be used. The approximate ranges of specific conductance for a variety of water types with the corresponding cell constants that would most likely produce accurate results are shown in figure 6.3-1. The user should check the meter specifications to verify that the meter and probe can be used to measure the entire range of expected specific conductance in the field.

\subsection{Equipment Maintenance}

Maintenance of specific conductance equipment includes periodic inspections of meters and probes and checks on instrument operation and performance.

- To maintain the specific conductance meter in good operating condition-

- Protect the meter and probe from excessive heat and cold. Keep the equipment free from dust and transport it in a designated case for protection during transport.

- Keep all cable connectors dry and free from dirt and salts.

- Ensure the batteries are adequately charged and corrosion free.
- Keep the probes clean. Probes may build up dirt and corrosion that can affect measurements; therefore, regular cleaning is required.

\subsubsection{Conductivity Probe Cleaning, Storage, and Maintenance}

Accurate and precise measurement of specific conductance requires a well-maintained and clean conductivity probe. A probe that is dirty or wet with solution other than the sample may contaminate the measured solution and bias the measurement of specific conductance. Conductivity probes must be clean and the electrodes free from scratches to produce accurate results. Refer to the manufacturer's instructions for storage and additional maintenance information.

\section{- To clean conductivity probes-}

- Clean the probe thoroughly by rinsing with copious amounts of deionized water (DIW) before and after making a measurement. This is sufficient cleaning in most cases.

- Epoxy and graphite conductivity probes can be gently wiped with a clean laboratory tissue to remove any residues.

- Never wipe or scour platinum-coated electrodes.

- Remove oily residues or other chemical residues with a detergent solution and then rinse thoroughly with DIW. Probes can soak in detergents for many hours without damage.

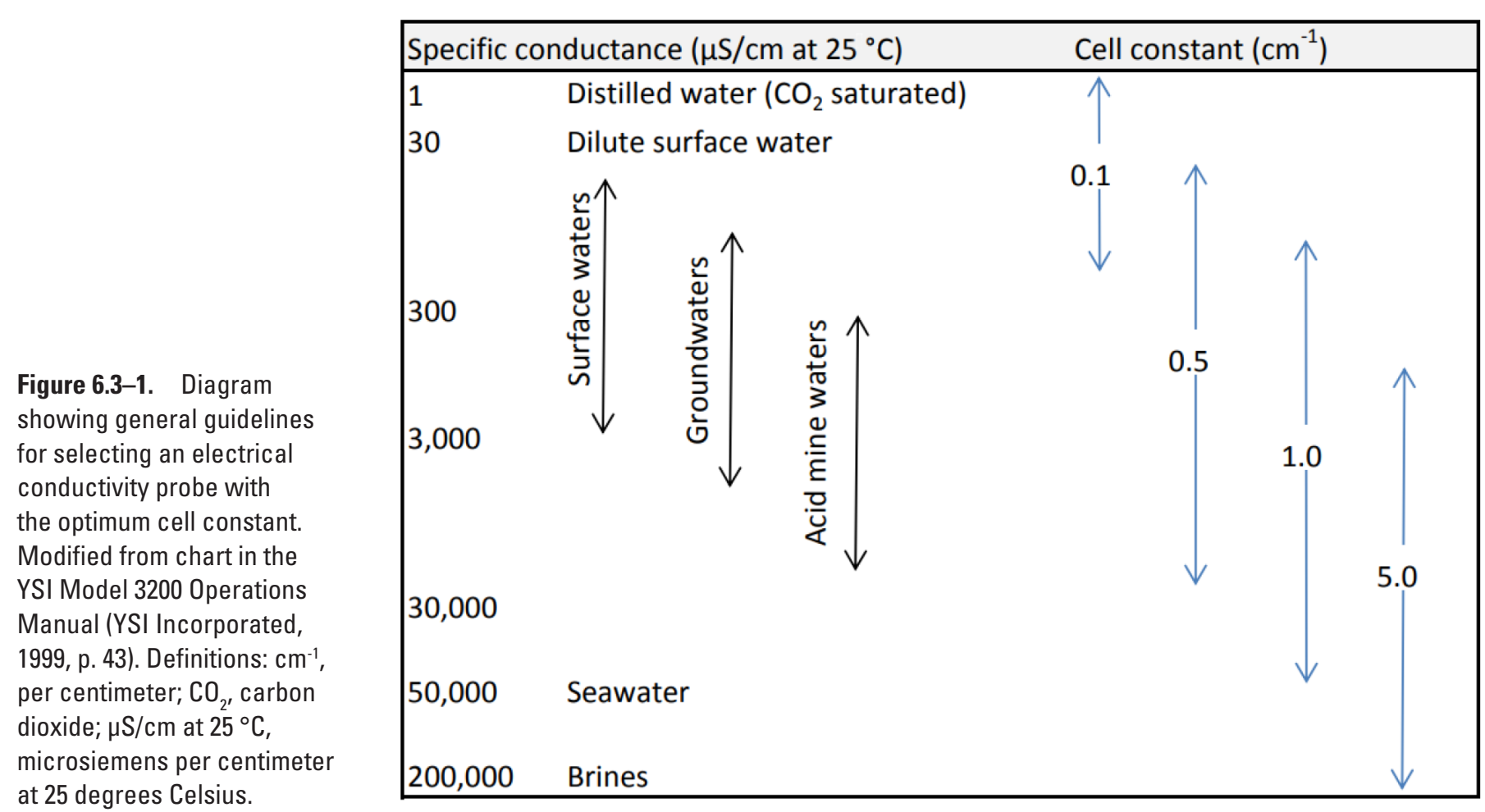


- When additional cleaning is required, soak the probe in 5-percent volume per volume (v/v) hydrochloric acid for as long as 2 hours and then rinse thoroughly with DIW. Check the manufacturer's recommendations before using acid.

- Caution: Platinum and platinum-iridium electrodes should not be cleaned in nitric acid $\left(\mathrm{HNO}_{3}\right)$, aqua regia, or any other solution that is known to etch platinum or gold.

Consult your instruction manual for specific storage instructions. Most conductivity probes, including probes with graphite electrodes, can be stored clean and dry; however, probes on multiparameter sondes are required to be stored in water (typically tap water) to prevent drying out of other sensors. Storage in water is acceptable while the probe is in use.

\subsection{Calibration}

Specific conductance measurements are only as good as the calibration itself. Several factors must be considered when calibrating the meter. Thermal expansion of the conductivity cell can affect the cell constant; however, the cell constants $\left(K_{\text {cell }}\right)$ of modern field probes are generally stable from 0 to $100^{\circ} \mathrm{C}$. Most conductivity standards are potassium chloride $(\mathrm{KCl})$ solutions, and the linear (0.019-0.020) and nonlinear (International Organization for Standardization, $1985)$ temperature-compensation factors $(\alpha)$ will produce reliable calibrations from 5 to $35^{\circ} \mathrm{C}$. Caution should be used when calibrating at temperatures greater than $35^{\circ} \mathrm{C}$, however, because the commonly used nonlinear (International Organization for Standardization, 1985) temperature compensation deviates substantially when applied to $\mathrm{KCl}$ solutions. Therefore, if a modern conductivity probe that expands minimally with temperature is used and the temperature of the water to be measured is between 5 and $35^{\circ} \mathrm{C}$, the temperature of the calibration solutions (either laboratory or in situ) is not expected to significantly affect the measurement of specific conductance of samples in the field.

Conductivity standards are susceptible to contamination or dilution from residual solutions, including rinse water, and each calibration should be done with care. Low-conductivity standards $(<200 \mu \mathrm{S} / \mathrm{cm})$ are especially susceptible to contamination. Calibration in the laboratory prior to field measurement, for both specific conductance meters and multiparameter sondes, is recommended because the temperature is regulated and the standard solutions are less susceptible to contamination.

Specific conductance meters must be checked or calibrated before every field trip to ensure that the meter and probe are working properly. The accuracy of specific conductance measurements should be checked in the laboratory and in the field by conducting measurements on standards whose specific conductance is near the expected specific conductance of the sample. Measurements of specific conductance standards that are within $\pm 5 \mu \mathrm{S} / \mathrm{cm}$ of the certified values for measurements $\leq 100 \mu \mathrm{S} / \mathrm{cm}$ or \pm 3 percent of the certified values for measurements $>100 \mu \mathrm{S} / \mathrm{cm}$ are considered accurate and do not warrant recalibration. Because specific conductance meters typically maintain their calibration, frequent recalibration is generally unnecessary and may not improve data accuracy. If calibration in the field is required, make certain the temperature of the standards is stable and between 5 and $35^{\circ} \mathrm{C}$.

Specific conductance meters utilize either a one- or a multipoint calibration procedure. Both calibration procedures work well and the instruction manual accompanying the specific conductance meter as well as the NFM should be followed closely. Record and track the cell constant (one-point calibration) or slope (multipoint calibration), as deviations can be used to identify inaccurate calibrations or faulty equipment. To verify that the specific conductance meter is responding properly at low values of specific conductance, check the zero response of the dry conductivity cell in air or DIW. The measured specific conductance of DIW should be $<3 \mu \mathrm{S} / \mathrm{cm}$.

Specific conductance meters are typically calibrated with $\mathrm{KCl}$ solutions of known concentration that are traceable to National Institute of Standards and Technology (NIST). Specific conductance standards with certificates of analyses (NIST traceable) with values between 50 and $50,000 \mu \mathrm{S} / \mathrm{cm}$ are available from USGS One Stop. ${ }^{1}$ Electrical conductivities of highly accurate $\mathrm{KCl}$ standards $(0.01,0.1$, and 1.0 mole per kilogram $[\mathrm{mol} / \mathrm{kg}]$ ) were determined by Pratt and others (2001) and are shown in table 6.3-2. Extreme care should be used when calibrating with dilute $(<\mathbf{2 0 0}-\mu \mathrm{S} / \mathrm{cm})$ solutions, as small amounts of contaminants or minor dilution can substantially affect the calibration. Triple rinsing with DIW and calibration standards is required. In addition to conductivity standards, the USGS Quality Systems Branch (QSB) provides a variety of standard reference samples (SRSs), prepared from natural waters, for quality-assurance testing and measurements of specific conductance.

\subsection{One-Point Calibration-Determination of the Cell Constant}

Many specific conductance meters and multiparameter sondes utilize a one-point calibration for measurement of specific conductance. Calibration of specific conductance meters using a one-point calibration involves determination of the cell constant $\left(K_{\text {cell }}\right)$ by measuring the conductance $(G)$ of a standard solution with a known conductivity $(\kappa)$ (see equation 1 , where the value of $\kappa$ is known). Meters utilizing one-point calibrations typically require calibration with

${ }^{1}$ Equipment and supplies that are tested and quality assured are available to USGS field studies from the National Field Supply Service (NFSS) and the Hydrologic Instrumentation Facility (HIF), and are sold through the USGS One Stop ordering system (accessed September 11, 2017, at https://1stop.usgs.gov/, internal USGS access only). 
Table 6.3-2. Electrical conductivity of molality-based primary $\mathrm{KCl}$ standards.

$[\mu \mathrm{S} / \mathrm{cm}$, microsiemens per centimeter; $\mathrm{m}$, molality in $\mathrm{mol} / \mathrm{kg}$ of solution; $\mathrm{mol} / \mathrm{kg}$, mole per kilogram; $\mathrm{KCl}$, potassium chloride; ${ }^{\circ} \mathrm{C}$, degrees Celsius; $\mathrm{CO}_{2}$, carbon dioxide; $\mathrm{H}_{2} \mathrm{O}$, water; - , not available]

\begin{tabular}{|c|c|c|c|}
\hline \multicolumn{4}{|c|}{ Electrical conductivity, in $\mu \mathrm{S} / \mathrm{cm}^{1}$} \\
\hline \multirow{2}{*}{$\begin{array}{c}\text { Temperature, } \\
\text { in }{ }^{\circ} \mathrm{C}\end{array}$} & \multicolumn{3}{|c|}{ Molality (m) of $\mathrm{KCl}$ solutions, in $\mathrm{mol} / \mathrm{kg}$} \\
\hline & 0.01 & 0.1 & 1.0 \\
\hline 0 & 773.50 & 7117.4 & 63489 \\
\hline 5 & 891.64 & 8184.4 & 72031 \\
\hline 10 & 1014.7 & 9292.5 & 80845 \\
\hline 15 & 1142.3 & 10438 & 89901 \\
\hline 18 & 1220.9 & 11142 & - \\
\hline 20 & 1274.0 & 11617 & 99171 \\
\hline 25 & 1409.3 & 12826 & 108620 \\
\hline 30 & 1547.8 & 14060 & 118240 \\
\hline 35 & 1689.1 & 15317 & 127970 \\
\hline 40 & 1832.7 & 16592 & 137810 \\
\hline 45 & 1978.1 & 17882 & 147720 \\
\hline 50 & 2125.0 & 19183 & 157670 \\
\hline
\end{tabular}

${ }^{1}$ Data from Pratt and others (2001). Values represent $\mathrm{CO}_{2}$-saturated $\mathrm{H}_{2} \mathrm{O}$.

standard solutions having specific conductance values of 500 , 1,413 , or $12,900 \mu \mathrm{S} / \mathrm{cm}$. Select the standard with a specific conductance that is closest to the expected specific conductance of the samples. Once the cell constant is determined, the conductivity of the environmental water sample is determined by using equation 1 and the specific conductance is determined by using equation 2 . The cell constant of many modern specific conductance probes is nearly constant $( \pm 2$ percent) over a wide range of concentration and temperature because the physical dimension of the cell does not change appreciably. Record and track the cell constant with each calibration, as changes in the cell constant that exceed 2 percent may be the result of a contaminated standard or dirty probe. After the meter is calibrated, check the accuracy of the calibration by measuring at least one additional specific conductance standard that brackets the expected range of environmental values to be measured. Measurements of specific conductance standards that are within $\pm 5 \mu \mathrm{S} / \mathrm{cm}$ of the certified values for measurements $\leq 100 \mu \mathrm{S} / \mathrm{cm}$ or \pm 3 percent of the certified values for measurements $>100 \mu \mathrm{S} / \mathrm{cm}$ are considered accurate and do not warrant recalibration.

\subsection{Multipoint Calibration}

Some specific conductance meters utilize a multipoint calibration method. For a multipoint calibration, the conductance is determined for standards, and the conductivity of the sample is determined by interpolation to a standard curve.
If the meter allows the user to select conductivity standards, choose standards that bracket the expected specific conductance of the samples. Record and track the slope and intercept with each calibration, as substantial changes may be the result of contaminated standards or a dirty probe. Bias can occur as a result of contamination as well as dilution from rinse water. DIW and calibration standards with values less than $200 \mu \mathrm{S} / \mathrm{cm}$ are susceptible to bias from dilution or contamination and are difficult to measure accurately. Therefore, it is recommended to calibrate specific conductance with standards with values that are greater than $200 \mu \mathrm{S} / \mathrm{cm}$. After the meter is calibrated, check the accuracy of the calibration by measuring the specific conductance of at least one additional standard near the expected range of environmental values to be measured. Measurements of specific conductance standards that are within $\pm 5 \mu \mathrm{S} / \mathrm{cm}$ of the certified values for measurements $\leq 100 \mu \mathrm{S} / \mathrm{cm}$ or \pm 3 percent of the certified values for measurements $>100 \mu \mathrm{S} / \mathrm{cm}$ are considered accurate and do not warrant recalibration.

Deionized water and calibration standards with specific conductance less than $200 \mu \mathrm{S} / \mathrm{cm}$ are susceptible to bias from dilution or contamination and are difficult to measure accurately. It is recommended to calibrate specific conductance with standards with values that are greater than $200 \mu \mathrm{S} / \mathrm{cm}$. After the meter is calibrated, check the accuracy of the calibration by measuring the specific conductance of standards near the expected range of environmental values to be measured.

\subsection{Meter Calibration Procedure}

The calibration procedure described in this section applies to most field specific conductance meters equipped with a probe containing a dip-style conductivity cell and builtin temperature compensation. Refer to the meter's manual for specific instructions. Calibration in the laboratory prior to field measurement is recommended because the temperature is regulated and the standard solutions are less susceptible to contamination. If calibration in the field is required, the same procedure should be followed. Make certain the temperature of the standards is stable and between 5 and $35^{\circ} \mathrm{C}$.

Calibration in the laboratory prior to field measurement is recommended because the temperature is regulated and the standard solutions are less susceptible to contamination.

- Meter calibration steps-

1. If possible, select a probe with a conductivity cell that will most accurately measure the expected specific conductance (fig. 6.3-1). However, many modern specific conductance meters and multipa- 
rameter sondes have one all-purpose conductivity cell designed to measure a wide range of specific conductance values in natural waters.

2. Inspect the meter and conductivity cell for damage. Check the batteries and change or charge the batteries if needed. Make sure the cables are clean and properly connected.

3. Select calibration standards. If possible, use specific conductance standards that bracket (multipoint calibration) or are near (one-point calibration) the expected specific conductance of the samples. Some meters utilize an automatic calibration procedure and can only be calibrated with standards having certain specific conductance (for example, 100, 500, 1,413, or $12,900 \mu \mathrm{S} / \mathrm{cm}$ ). For a multipoint calibration, begin the calibration with the standard that has the lowest specific conductance and continue the calibration by using standards in ascending order. Use fresh standards and verify that the date on the standards has not expired. Do not use expired standards.

4. Fill the calibration cup or beaker to about one third full with DIW. Place the probe in the beaker or calibration cup and thoroughly rinse the probe (note that some probes on multiparameter sondes require an aggressive rinse procedure). Rinse the probe with the DIW from the cup or beaker and shake off the excess liquid. Dispose of the solution. Repeat this procedure for a total of three times. Do not calibrate using DIW; however, the measured specific conductance of DIW should be $<3 \mu \mathrm{S} / \mathrm{cm}$.

5. Fill the calibration cup or beaker to about onethird full with the specific conductance standard. For a one-point calibration, this will be a standard chosen that is near the expected specific conductance of the sample. For a multipoint calibration, this will be the specific conductance standard with the lowest value of the standards that have been chosen for the calibration. Place the probe in the calibration cup or beaker and swirl the probe to thoroughly rinse. Ensure that the conductivity cell (all electrodes on the probe) is completely submerged. Rinse the probe with a small amount of the standard and shake off excess liquid. Dispose of the solution. Repeat this procedure for a total of three times.

6. Fill the calibration cup or beaker with the specific conductance standard, place the probe in the solution, gently swirl the solution to ensure all air bubbles are removed from the cell, and allow the solution and probe to equilibrate. Monitor the temperature and conductance, and when both are stable, begin the calibration following the meter's calibration procedure.

7. For one-point calibration, the cell constant can now be determined. For multipoint calibration, the calibration of the first point can now be determined. For a multipoint calibration, repeat steps 4 through 6 for each standard, beginning with the lowest conductivity standard and continuing the calibration in ascending order.

8. Record the following in the instrument log book, field sheets, or personal computing field forms (PCFFs):

a. The concentrations and lot numbers of the conductivity standards and their known and measured specific conductance,

b. The temperature of the standard solution,

c. The water-temperature compensation utilized (unless the user changes the settings or uses a low-pH conductivity method, the temperature compensation may only need to be recorded once in the log book),

d. The cell constant (one-point calibration) or the slope and intercept (multipoint calibration), and

e. The meter type, meter serial number, and probe serial number.

9. Verify that the new calibration parameters are consistent with previous calibrations and are within the limits established by the manufacturer.

10. Discard the standard solution into a waste container, thoroughly rinse the cell with DIW, and dry.

11. Check the accuracy of the calibration by measuring at least one additional standard. For a one-point calibration, the additional standard should be one that brackets the expected specific conductance value of the sample. For a multipoint calibration, the additional standard should have a value near the expected range of environmental values to be measured. The specific conductance of USGS SRSs also can be measured to check accuracy. The specific conductance of check standards should be within $\pm 5 \mu \mathrm{S} /$ $\mathrm{cm}$ for measurements $\leq 100 \mu \mathrm{S} / \mathrm{cm}$ or \pm 3 percent for measurements $>100 \mu \mathrm{S} / \mathrm{cm}$. Recalibrate the specific conductance meter if the measured specific conductance of the check standards does not meet the calibration criteria. 


\subsection{Measurement of Specific Conductance}

In situ measurements generally are preferred for determining the specific conductance of surface water, and downhole or flow-through cell measurements are preferred for groundwater. Specific conductance is typically determined on an unfiltered sample.

- The following precautions should be taken when measuring specific conductance-

- It is best to measure the specific conductance of the sample in situ because the specific conductance of water can change over time as a result of chemical and physical processes such as precipitation, adsorption, degassing, and oxidation.

- If a measurement cannot be made in situ and the water is highly susceptible to substantial gain or loss of dissolved gases, make the measurement from a composited or discrete subsample within a triple-rinsed, gas-impermeable container fitted with a stopper. Measure the specific conductance as soon as possible and try to maintain the sample at the temperature at which it was collected. Gas-bubble formation on the probe surface or gases flowing over the surface will result in an inaccurate reading.

- When using multiparameter sondes, avoid contamination from the $\mathrm{pH}$ electrode-filling solution and calibration buffers. The $\mathrm{pH}$ buffers and filling solutions have high ionic strengths and are a potential source of contamination. When calibrating multiparameter sondes, calibrate specific conductance before $\mathrm{pH}$.

- When measuring the specific conductance of flowing water, make sure that the conductivity cell has no cavitation or air bubbles. If the water velocity is too high to measure the specific conductance accurately, relocate the probe to an area with lower velocity or measure the specific conductance of a representative subsample as soon as possible.

- The stability criterion for recording a specific conductance measurement in the field is $\pm 5 \mu \mathrm{S} / \mathrm{cm}$ for measurements $\leq 100 \mu \mathrm{S} / \mathrm{cm}$ or \pm 3 percent for measurements $>100 \mu \mathrm{S} / \mathrm{cm}$. A measurement outside the criterion is likely the result of air or cavitation within the conductivity cell, a faulty meter, or poor mixing of the measured water, causing its composition to change rapidly.

- Standard temperature-compensation factors (either linear [0.019-0.020 per ${ }^{\circ} \mathrm{C}$ ] or nonlinear [International Organization for Standardization,
1985]) should be utilized for samples with $\mathrm{pH}$ between 4 and 11 and temperature between 5 and $35^{\circ} \mathrm{C}$.

\subsection{Measurement of Specific Conductance in Surface Water}

Specific conductance of surface water should be measured in situ if practical; otherwise, measure specific conductance in discrete samples collected from a sample splitter or compositing device.

\subsubsection{In Situ Measurement of Specific Conductance in Surface Water}

Measurements of specific conductance in flowing surface water should represent the cross-sectional mean or median specific conductance at the time of observation. Any deviation from this convention must be documented in the database and with the published data. This requirement is especially important for poorly mixed streams at points downstream from a convergence or source of drainage.

- Before making a measurement of specific conductance-

- If you are unfamiliar with the sample site, measure a depth and cross-sectional specific conductance profile to determine the degree of system variability. A dip-style conductivity probe works best for this purpose.

- Refer to NFM A6.0 for information on which sampling method to use.

- To measure specific conductance in surface water-

1. Check the accuracy of the specific conductance measurement at the field site by measuring the specific conductance of a check standard. Select a check standard with a specific conductance similar to that of the sample. The specific conductance of check standards should be within $\pm 5 \mu \mathrm{S} / \mathrm{cm}$ for measurements $\leq 100 \mu \mathrm{S} / \mathrm{cm}$ or \pm 3 percent for measurements $>100 \mu \mathrm{S} / \mathrm{cm}$. Recalibrate if necessary.

2. Determine the variation of specific conductance along a cross-sectional profile using an appropriate measurement method (see NFM A6.0; use equal-width increment [EWI] or equal-discharge increment [EDI] method if required):

a. If the stream is flowing and wadable, wade to the location(s) where specific conductance is to be measured. 
b. If the stream is too deep or swift to wade, lower a conductivity probe from a bridge, cableway, or boat.

c. For still-water conditions in streams, measure specific conductance at multiple depths at several points in the cross section.

d. For large still-water bodies such as lakes, reservoirs, and estuaries, measure specific conductance at multiple depths and locations depending on the study objectives.

3. Immerse the specific conductance probe in the water to the appropriate depth and hold (not less than 60 seconds) until the probe equilibrates to water conditions. Determine equilibration by observing stability of the reading. Always keep probes above the streambed so as not to immerse the sensor into bed sediments, which can bias readings.

4. Record the measurements of specific conductance and temperature without removing the probes from the water.

a. Consecutive measurements should meet the stability criterion $( \pm 5 \mu \mathrm{S} / \mathrm{cm}$ for measurements $\leq 100 \mu \mathrm{S} / \mathrm{cm}$ or \pm 3 percent for measurements $>100 \mu \mathrm{S} / \mathrm{cm}$ ).

b. Record the stabilized value on field forms.

c. If the readings do not meet the stability criterion after extending the measurement period, record this difficulty in the field notes along with the fluctuation range and the median value of the last five or more readings. Consider troubleshooting the measurement (see section 5.0) or using a different specific conductance meter.

5. For measurements made using EWI or EDI methods, proceed to the next station in the cross section and repeat steps 3 and 4. Record on field forms the stable value for each subsection measured.

6. When the measurements are completed, remove the probe from the water, rinse it with DIW, and store the meter and probe in a protective case.

7. Record specific conductance and temperature on the field sheet following the procedures described in NFM A6.0 for still-water, EDI, or EWI measurement methods. Refer to section 6.0 below for reporting of specific conductance values.

\subsubsection{Measurement of Specific Conductance on a Subsample from Surface Water}

Representative samples for analysis of water quality are collected and split or composited according to approved USGS methods (NFM A4). Measure the specific conductance of these composited subsamples as soon as possible after collection. If the sample cannot be analyzed immediately, fill a clean and triple-rinsed bottle completely to the top, cap it tightly, and attempt to maintain the sample at stream temperature until measurement. Reported values of specific conductance typically are determined on an unfiltered sample.

\section{- High concentrations of suspended sediment can be a source of measurement error-record such condi- tions in the field notes.}

- If there appears to be a lot of suspended sediment in the water sample, measure the specific conductance of both unfiltered and filtered subsamples and record both values on the field form. High concentrations of suspended sediments may interfere with the measurement of specific conductance, and the inference may vary from site to site depending on the type, size, and concentration of suspended sediments.

- If the values of specific conductance for the filtered and unfiltered samples differ by more than $\pm 5 \mu \mathrm{S} /$ $\mathrm{cm}$ for measurements $\leq 100 \mu \mathrm{S} / \mathrm{cm}$ or \pm 3 percent for measurements $>100 \mu \mathrm{S} / \mathrm{cm}$, report the filtered value and identify it as having been measured on a "filtered sample."

\section{- Steps to measure specific conductance on a subsample of surface water-}

1. Check the accuracy of the specific conductance measurement at the field site by measuring the specific conductance of a check standard. Select a check standard with a specific conductance similar to that of the sample. The specific conductance of check standards should be within $\pm 5 \mu \mathrm{S} / \mathrm{cm}$ for measurements $\leq 100 \mu \mathrm{S} / \mathrm{cm}$ or \pm 3 percent for measurements $>100 \mu \mathrm{S} / \mathrm{cm}$. Recalibrate if necessary.

2. Select the sampling method (see NFM A6.0) and collect a representative sample.

3. Withdraw a homogenized subsample from a sample splitter or compositing device. Rinse a clean sample bottle three times with the sample. For filtered samples, rinse with sample filtrate.

4. Prepare the specific conductance probe for sample measurement: 
a. First, rinse the specific conductance probe and the container three times with DIW.

b. Next, rinse the specific conductance probe and the container three times with sample water.

5. Allow the probe to equilibrate to sample temperature, then discard the sample water. Pour fresh sample water into a container holding the probe, as described by the manufacturer to avoid fringe field interferences.

6. Allow the probe to thermally equilibrate to the water temperature by monitoring the temperature.

7. Measure specific conductance.

a. Remove any air trapped in the sensor by gently swirling the probe up and down under the water surface.

b. Read the meter display.

c. Gently swirl the sensor up and down under the water surface, and read the display again.

d. Repeat the procedure until consecutive readings are the same. Consecutive measurements should meet the stability criterion ( $\pm 5 \mu \mathrm{S} / \mathrm{cm}$ for measurements $\leq 100 \mu \mathrm{S} / \mathrm{cm}$ or \pm 3 percent for measurements $>100 \mu \mathrm{S} / \mathrm{cm}$ ).

8. Record specific conductance and temperature on the field sheet. Refer to section 6.0 below for reporting of specific conductance values.

9. Collect replicates for quality control.

a. Repeat steps $4 \mathrm{~b}$ through 8 with at least two fresh subsamples, rinsing the probes only once with sample water.

b. Subsample values should be within $\pm 5 \mu \mathrm{S} / \mathrm{cm}$ for specific conductance $\leq 100 \mu \mathrm{S} / \mathrm{cm}$ or \pm 3 percent for specific conductance $>100 \mu \mathrm{S} / \mathrm{cm}$.

c. If criteria cannot be met, filter the samples, report the value of specific conductance of three or more samples, and record this difficulty in the field notes.

10. Rinse the probe and the container with DIW and store the meter and probe as directed by the manufacturer in a protective case.

\subsection{Measurement of Specific Conductance in Groundwater}

Measurements of specific conductance in groundwater must be representative of aquifer conditions. Temperature and redox changes resulting from transporting a sample from the aquifer to land surface can affect measurements of specific conductance.

- To minimize environmental effects on measurements of specific conductance in wells-

- Measure specific conductance as close to the source as possible, using either a downhole or flow-through chamber sampling system (refer to NFM A6.0 for details).

- Bailing or other methods for collecting discrete samples isolated from the source are not recommended as standard practice for the measurement of specific conductance, although such methods are sometimes called for owing to site characteristics or other study requirements.

- The well should be purged or in the process of purging before sample specific conductance is measured and recorded. During purging, confirm that readings of temperature and specific conductance have stabilized before proceeding with specific conductance measurements.

\subsubsection{Measurement of Specific Conductance in a Well}

- For measurements of specific conductance downhole or in a flow-through chamber with water pumped from a well-

1. Check the accuracy of the specific conductance measurement at the field site by measuring the specific conductance of a check standard. Select a check standard with a specific conductance similar to that of the sample. The specific conductance of check standards should be within $\pm 5 \mu \mathrm{S} / \mathrm{cm}$ for measurements $\leq 100 \mu \mathrm{S} / \mathrm{cm}$ or \pm 3 percent for measurements $>100 \mu \mathrm{S} / \mathrm{cm}$. Recalibrate if necessary.

2. Install the specific conductance probe.

a. For measurement in a downhole system-

i. Lower the probe to the sampling point.

ii. Remove air trapped in the conductivity cell by gently moving the probe up and down under the water; read the meter display. 
iii. Repeat this procedure until the specific conductance measurement is stable. Consecutive measurements should meet the stability criterion $( \pm 5 \mu \mathrm{S} / \mathrm{cm}$ for measurements $\leq 100 \mu \mathrm{S} / \mathrm{cm}$ or \pm 3 percent for measurements $>100 \mu \mathrm{S} / \mathrm{cm})$.

b. For measurement with a pumped flow-cell system-

i. Install the flow-cell system as close to the well as possible and shield the system from direct sunlight.

ii. Depending on the flow-cell design, position the specific conductance probe upstream from the $\mathrm{pH}$ electrode.

iii. Direct water flow to the flow cell after an initial discharge of waste to clear sediment and other contaminants from the sample line.

iv. Release air trapped in the chamber and ensure air is not trapped in the conductivity cell.

v. Consecutive measurements should meet the stability criterion ( $\pm 5 \mu \mathrm{S} / \mathrm{cm}$ for measurements $\leq 100 \mu \mathrm{S} / \mathrm{cm}$ or \pm 3 percent for measurements $>100 \mu \mathrm{S} / \mathrm{cm})$. If the readings are not consistent, air may be trapped in the cell.

3. While purging the well, maintain a constant flow rate.

4. Allow the probe to thermally equilibrate with groundwater temperature for 5 minutes or more at the flow rate to be used for collecting all other samples.

5. Measure specific conductance and temperature at regular intervals throughout purging; record the values of specific conductance and the associated temperatures on field forms.

6. Check the variability of the measured specific conductance toward the end of purging.

a. The specific conductance stability criterion is met when five measurements made at regularly spaced intervals of 3 to 5 minutes or more are within $\pm 5 \mu \mathrm{S} / \mathrm{cm}$ for specific conductance $\leq 100 \mu \mathrm{S} / \mathrm{cm}$ or \pm 3 percent for specific conductance $>100 \mu \mathrm{S} / \mathrm{cm}$. b. When readings fluctuate rapidly, record the median of three or more readings within approximately 60 seconds as the value for a specific time interval.

c. If the stability criterion is not met, extend the purge period in accordance with study objectives and continue to record measurements at regularly spaced time intervals. Record this difficulty on the field forms.

7. Report the specific conductance and temperature.

a. Record the final five values on the field sheet.

b. Report the median value of the final five specific conductance values. Refer to section 6.0 below for reporting of specific conductance values.

c. If the stability criterion is not met, report the range of values observed for the time interval on the field sheet, along with the median of the final five or more values. Consider troubleshooting the measurement (see section 5.0) or using a different specific conductance meter.

\subsubsection{Measurement of Specific Conductance on a Subsample from a Well}

Specific conductance measurements reported from bailed or other discrete samples need to be identified in the database, indicating the sampling method used. Refer to NFM A6.0 for use of bailers and the subsample method.

- To measure specific conductance on a bailed or discrete groundwater sample-

1. Check the accuracy of the specific conductance measurement at the field site by measuring the specific conductance of a check standard. Select a check standard with a specific conductance similar to that of the sample. The specific conductance of check standards should be within $\pm 5 \mu \mathrm{S} / \mathrm{cm}$ for measurements $\leq 100 \mu \mathrm{S} / \mathrm{cm}$ or \pm 3 percent for measurements $>100 \mu \mathrm{S} / \mathrm{cm}$. Recalibrate if necessary.

2. Draw off subsamples for measurement.

3. If samples need to be stored for a short time, or if measurements will be made on several subsamples, collect sample aliquots in separate field-rinsed bottles - fill completely with no headspace, cap tightly, and maintain at ambient groundwater temperature. Measure specific conductance as soon as possible. 


\section{TECHNICAL NOTES:}

- If the measurement is made on a sample in an open container and readings do not stabilize within several minutes, the cause may be $\mathrm{CO}_{2}$ degassing. Use a closed system to make the measurement.

- Filter a sample to measure specific conductance if clay or other suspended particles interfere with the stability of the readings.

\subsection{Measurement of Specific Conductance of a Water Sample with Low or High pH}

Specific conductance (and electrical conductivity) data are reported at $25^{\circ} \mathrm{C}$. Most modern specific conductance meters have the capability to compensate for temperature automatically. Equation 2 is used most commonly to determine the specific conductance at $25^{\circ} \mathrm{C}$ and commercially available field specific conductance meters typically use either a constant $\alpha$ (typically $0.019-0.020$ per $^{\circ} \mathrm{C}$ ) or a nonlinear $\alpha$ (International Organization for Standardization, 1985). Whereas these commonly used temperature-compensation factors work well for waters having a $\mathrm{pH}$ between 4 and 11, they can be the source of errors as large as 50 percent for low-pH samples.

\subsubsection{Measurement of Specific Conductance of a Water Sample with Low pH $(<4)$}

The specific conductance measurement error for low-pH $(<4)$ waters can be large if the commonly used temperaturecompensation factors are used. To determine whether an alternative temperature-compensation method should be used for samples with $\mathrm{pH}<4$, the in situ specific conductance should be compared to the specific conductance of a sample equilibrated to $25^{\circ} \mathrm{C}$. If the measurements are comparable (within $\pm 5 \mu \mathrm{S} / \mathrm{cm}$ for specific conductance $\leq 100 \mu \mathrm{S} / \mathrm{cm}$ or \pm 3 percent for specific conductance $>100 \mu \mathrm{S} / \mathrm{cm}$ ), then the temperature algorithm used is likely sufficient. If a temperature-compensation factor is required for a water sample with $\mathrm{pH}<4$, the method described by McCleskey (2013) is recommended.

\subsubsection{Measurement of Specific Conductance of a Water Sample with High pH (>11)}

No temperature-compensation method is available for waters with high $\mathrm{pH}(>11)$; therefore, the specific conductance should be checked by making a measurement at ambient temperature and at $25{ }^{\circ} \mathrm{C}$ for waters with $\mathrm{pH}>11$. At high $\mathrm{pH}$, hydroxide becomes a major ion in the solution and its mobility is different than that of most other ions. However, the hydroxide-equivalent conductivity is much lower than the hydrogenequivalent conductivity and, unlike in low-pH waters, the standard temperature-compensation approaches may be adequate. Furthermore, relatively few natural waters have a $\mathrm{pH}>11$, so this situation is fairly rare.

\subsection{Troubleshooting}

Contact the instrument manufacturer if the actions suggested in table 6.3-3 fail to resolve the problem. One of the first things to check is the battery voltage. Always have fresh batteries in meters and carry spares when taking meters out into the field.

Check the voltage of batteries. Always have fresh batteries in field meters and carry spares.

\subsection{Reporting Specific Conductance in Natural Waters}

- Follow USGS standard protocols for reporting specific conductance in the National Water Information System (NWIS) database-

- Report the value on the field forms to three significant figures for specific conductance $\geq 100 \mu \mathrm{S} / \mathrm{cm}$ or two significant figures for specific conductance $<100$ $\mu \mathrm{S} / \mathrm{cm}$.

- Enter field-determined specific conductance measurements on the USGS National Water Quality Laboratory (NWQL) Analytical Services Request (ASR) form using the correct parameter code.

- Report the temperature-compensation factor in the comment field if a nonstandard temperature compensation is utilized (for example, if the low-pH temperature-compensation method is used).

\subsection{Uncertainty in Measurements of Specific Conductance}

The primary sources of uncertainty for specific conductance measurements are quality of calibration standards, temperature compensation, quality of the specific conductance meter and probe, and contamination of the sample during measurement. The uncertainty for most routine specific conductance measurements is estimated to be $<5 \mu \mathrm{S} / \mathrm{cm}$ for specific conductance $\leq 100 \mu \mathrm{S} / \mathrm{cm}$ or $<3$ percent of the most probable value for specific conductance $>100 \mu \mathrm{S} / \mathrm{cm}$. This uncertainty was estimated by using results from multiple interlaboratory comparison studies performed by the USGS QSB. Comparison studies of specific conductance were conducted over 19 years, and included 74 SRSs whose specific conductance ranged from 5 to $1,100 \mu \mathrm{S} / \mathrm{cm} ; 16$ to 93 laboratories participated in each SRS study. The QSB provides SRSs for specific conductance quality-assurance testing. Additionally, all USGS WMA personnel who measure specific conductance 
Table 6.3-3. Troubleshooting guide for measurements of specific conductance.

$\left[>\right.$, Greater than; $\leq$, less than or equal to; $\mathrm{HCl}$, hydrochloric acid; $\mu \mathrm{S} / \mathrm{cm}$, microsiemens per centimeter; ${ }^{\circ} \mathrm{C}$, degrees $\mathrm{Cel}$ sius $]$

\begin{tabular}{|c|c|}
\hline Symptom & Possible cause and corrective action \\
\hline $\begin{array}{l}\text { Meter will not calibrate to standards } \\
\text { or will not accurately read } \\
\text { standards }\end{array}$ & $\begin{array}{l}\text { - Standards may be old or contaminated-use fresh standards. } \\
\text { - Electrodes dirty-first clean with a detergent solution, then if necessary with 5-percent HCl. } \\
\text { Before using any acid solution to remove resistant residues, check manufacturer's guidelines. } \\
\text { - Air trapped in conductivity sensor-gently move sensor up and down to expel trapped air. } \\
\text { - Weak or corroded batteries — replace. } \\
\text { - Temperature compensation incorrect—ensure that thermistor is operating properly. } \\
\text { - Multiparameter sonde inadequately rinsed — repeat rinsing. }\end{array}$ \\
\hline Erratic readings & 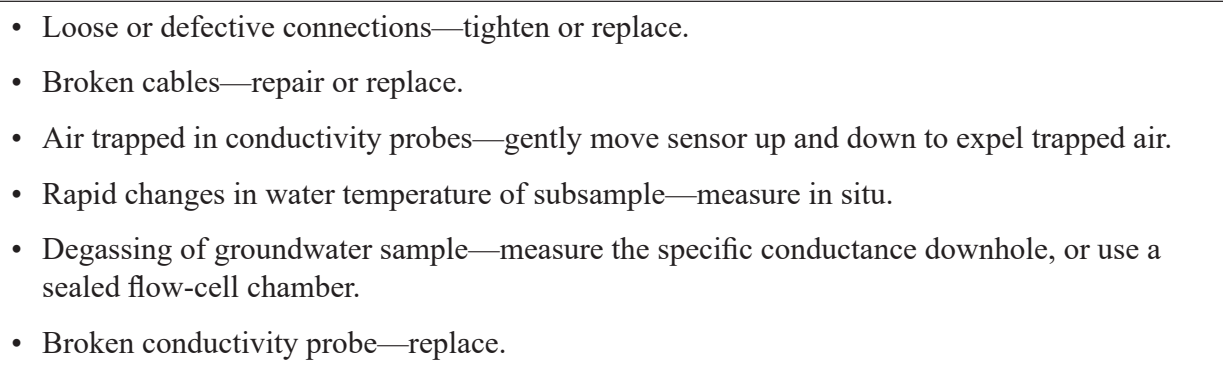 \\
\hline $\begin{array}{l}\text { Specific conductance meter requires } \\
\text { frequent recalibration }\end{array}$ & $\begin{array}{l}\text { Temperature compensation may not be working-measure specific conductance of a solution. } \\
\text { Place solution in a water bath and raise solution temperature to about } 25^{\circ} \mathrm{C} \text {. Measure specific } \\
\text { conductance again, allowing sufficient time for the probe to equilibrate to temperature of solu- } \\
\text { tion. If the two values differ by } \pm 5 \mu \mathrm{S} / \mathrm{cm} \text { for specific conductance } \leq 100 \mu \mathrm{S} / \mathrm{cm} \text { or } \pm 3 \text { percent } \\
\text { for specific conductance }>100 \mu \mathrm{S} / \mathrm{cm} \text {, check the temperature-compensation settings on the } \\
\text { meter, check the thermistor, and consider replacing the conductivity probe. }\end{array}$ \\
\hline $\begin{array}{l}\text { Specific conductance reading is } \\
\text { drifting or variable }\end{array}$ & $\begin{array}{l}\text { - Insufficient equilibration - allow conductivity cell to thermally equilibrate with water samples } \\
\text { and repeat measurements. } \\
\text { - Probe dirty or malfunctioning — clean or replace conductivity probe. }\end{array}$ \\
\hline
\end{tabular}

are required to participate in the National Field Quality Assurance project (NFQA), whereby samples of known values of specific conductance are distributed annually to test the proficiency of the analysts and accuracy of the equipment.

The primary sources of uncertainty for specific conductance measurements are quality of calibration standards, temperature compensation, quality of the specific conductance meter and probe, and contamination of the sample during measurement.

\subsection{Applications of Specific Conductance in Surface Water and Groundwater}

Measurements of specific conductance have been used to estimate the salinity of (Lewis, 1980), ionic strength of (Lind, 1970), and concentrations of major solutes (McCleskey and others, 2012a) and TDS (Hem, 1985) in natural waters. In addition, the specific conductance and the relative contribution of a given ion to the overall specific conductance (known as the transport number) can be calculated from chemical analyses (McCleskey and others, 2012b). The USGS geochemical speciation codes WATEQ4F (Ball and Nordstrom, 1991) and PHREEQC (Parkhurst and Appelo, 1999) have the capability to estimate the specific conductance of natural waters by using the concentrations of dissolved species. The relative percent difference between measured and calculated specific conductance can be used together with charge balance as a quality-control check for water analyses (McCleskey and others, 2012b). It is also possible to compare the concentration of TDS in milligrams per liter $(\mathrm{mg} / \mathrm{L})$ to specific conductance 
in microsiemens per centimeter $(\mu \mathrm{S} / \mathrm{cm})$ where the ratio is expected to be between 0.5 and 0.9 (Hem, 1985).

$$
\frac{\mathrm{TDS} \text { in } \mathrm{mg} / \mathrm{L}}{\text { specific conductance in } \mu \mathrm{S} / \mathrm{cm}} \approx 0.5 \text { to } 0.9
$$

Measurements of specific conductance are commonly used to estimate the salinity of water.

\section{Acknowledgments}

The information included in the U.S. Geological Survey (USGS) National Field Manual (NFM) is based on existing manuals, various reference documents, and a broad spectrum of expertise provided by USGS colleagues. Authors of previous versions of NFM chapter A6.3 were D.B. Radtke, J.V. Davis, and F.D. Wilde, whose expertise and integrity provided the groundwork for this and future versions of this chapter. The persistence and spirit that all of our USGS colleagues brought to the development of a national field manual were invaluable.

The following USGS colleagues provided detailed technical content and reviews that improved the quality of this report: R. Blaine McCleskey, Gerolamo Casile, Joseph Domagalski, Michael Manning, Cherie Miller, Michael Rosen, Stanley Skrobialowski, and Teri Snazell. Editorial and production assistance from Marilyn Billone, Sandy Cooper, Elizabeth Good, Cathy Knutson, Katharine Schindler, and Dale Simmons is greatly appreciated. These individuals contributed to the accuracy, quality, and usability of the NFM, and demonstrated much patience as we traversed the difficult task of developing the new format.

Special thanks are extended to Franceska Wilde (USGS), who led the effort for the NFM from its inception until her retirement in 2014; the USGS NFM Steering Committee (Gerolamo Casile, Michael Manning, Cherie Miller, Callie Oblinger (retired), Timothy Oden, Lisa Olsen, Michael Rosen, and Stanley Skrobialowski); Cherie Miller, who led the effort from 2016 to 2018; and Gerolamo Casile, who assumed responsibility for the NFM in 2018.

\section{References Cited}

Ball, J.W., and Nordstrom, D.K., 1991, User's manual for WATEQ4F, with revised thermodynamic data base and test cases for calculating speciation of major, trace, and redox elements in natural waters (ver. 2.0): U.S. Geological Survey Open-File Report 91-183, 189 p., accessed September 11, 2017, at https://pubs.er.usgs.gov/publication/ ofr91183.
Hem, J.D., 1982, Conductance-A collective measure of dissolved ions, in Minear, R.A., and Keith, L.H., eds., Water analysis - v. 1 Inorganic species, part 1: Orlando, Fla., Academic Press, Inc., p. 137-161.

Hem, J.D., 1985, Study and interpretation of the chemical characteristics of natural water ( $3 \mathrm{~d}$ ed.): U.S. Geological Survey Water-Supply Paper 2254, 264 p., accessed September 11, 2017, at https://pubs.usgs.gov/wsp/wsp2254/.

International Organization for Standardization, 1985, International Standard ISO-7888, Water qualityDetermination of electrical conductivity: Geneva, Switzerland, International Organization for Standardization, $6 \mathrm{p}$.

Lewis, E.L., 1980, The practical salinity scale 1978 and its antecedents: IEEE Journal of Oceanic Engineering, v. 5, no. 1, p. 3-8. [Also available at https://doi.org/10.1109/ JOE.1980.1145448.]

Lind, C.J., 1970, Specific conductance as a means of estimating ionic strength, in Geological Survey Research 1970: U.S. Geological Survey Professional Paper 700-D, p. D272-D280, accessed September 11, 2017, at https://pubs.er.usgs.gov/publication/pp700D.

McCleskey, R.B., 2013, New method for electrical conductivity temperature compensation: Environmental Science and Technology, v. 47, no. 17, p. 9874-9881. [Also available at https://doi.org/10.1021/es4021888r.]

McCleskey, R.B., Clor, L.E., Lowenstern, J.B., Evans, W.C., Nordstrom, D.K., Heasler, Henry, and Huebner, M.A., 2012a, Solute and geothermal flux monitoring using electrical conductivity in the Madison, Firehole, and Gibbon Rivers, Yellowstone National Park: Applied Geochemistry, v. 27, no. 12, p. 2370-2381. [Also available at https://doi.org/10.1016/j.apgeochem.2012.07.019.]

McCleskey, R.B., Nordstrom, D.K., Ryan, J.N., and Ball, J.W., 2012b, A new method of calculating electrical conductivity with applications to natural waters: Geochimica et Cosmochimica Acta, v. 77, p. 369-382. [Also available at https://doi.org/10.1016/j.gca.2011.10.031.]

Parkhurst, D.L., and Appelo, C.A.J., 1999, User's guide to PHREEQC (ver. 2)-A computer program for speciation, batch-reaction, one-dimensional transport, and inverse geochemical calculations: U.S. Geological Survey WaterResources Investigations Report 99-4259, 312 p., accessed September 11, 2017, at https://pubs.er.usgs.gov/publication/ wri994259.

Pratt, K.W., Koch, W.F., Wu, Y.C., and Berezansky, P.A., 2001, Molality-based primary standards of electrolytic conductivity: Pure and Applied Chemistry, v. 73, no. 11, p. 1783-1793. [Also available at http://users.unimi.it/ ECEA/IUPAC.pdf.] 
Radtke, D.B., Davis, J.V., and Wilde, F.D., 2005, Specific electrical conductance (ver. 1.2): U.S. Geological Survey Techniques of Water-Resources Investigations, book 9, chap. A6.3, 22 p. [Also available at https://pubs.er.usgs.gov/ publication/twri09A6.3.]

Robinson, R.A., and Stokes, R.H., 1970, Electrolyte solutions ( $2 \mathrm{~d}$ ed.): London, Butterworth \& Company Publishers Limited, $571 \mathrm{p}$.

U.S. Geological Survey, 2002, Water-quality field methods/ National Field Manual for the Collection of WaterQuality Data: U.S. Geological Survey Office of Water Quality Technical Memorandum 2002.13, accessed September 11, 2017, at https://water.usgs.gov/admin/memo/ QW/qw02.13.html.
U.S. Geological Survey, 2018, General introduction for the "National Field Manual for the Collection of Water-Quality Data" (ver. 1.1, June 2018): U.S. Geological Survey Techniques and Methods, book 9, chap. A0, 4 p., accessed June 22, 2018, at https://doi.org/10.3133/tm9A0.

YSI Incorporated, 1999, YSI Model 3200 conductance, resistance, salinity, total dissolved solids and temperature instrument - Operations manual, accessed July 28, 2018, at https://www.ysi.com/File\%20Library/Documents/ Manuals/003224-YSI-3200-Operations-Manual-RevF.pdf. 


\section{$\frac{\mathbb{2}}{\mathrm{C}}$}

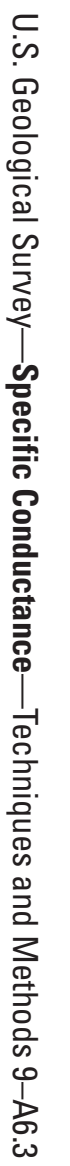

